\title{
PENGISIAN JABATAN GUBERNUR DAN WAKIL GUBERNUR DAERAH ISTIMEWA YOGYAKARTA BERDASAR UNDANG-UNDANG NOMOR 13 TAHUN 2012 TENTANG KEISTIMEWAAN DAERAH ISTIMEWA YOGYAKARTA
}

Oleh :

\section{BINOV HANDITYA}

Fakultas Hukum Universitas Ngudi Waluyo binovhanditya24@gmail.com

\begin{abstract}
ABSTRAK
Negara Kesatuan Republik Indonesia mengakui dan menghormati satuan-satuan pemerintahan daerah yang bersifat khusus atau bersifat istimewa yang diatur dengan undang-undang. Negara juga menghormati kesatuan-kesatuan masyarakat hukum adat serta hak-hak tradisonalnya sepanjang masih hidup dan sesuai dengan perkembangan masyarakat dan prinsip Negara Kesatuan Republik Indonesia, yang diatur dalam undang-undang. Dengan adanya hal tersebut di atas maka pelaksanaan pemilihan kepala daerah di daerah tersebut terpengaruh oleh kesatuan-kesatuan masyarakat hukum adat serta hak-hak tradisonalnya sepanjang masih hidup dan sesuai dengan perkembangan masyarakat. Dengan adanya Undang-undang Keistimewaan Daerah Istimewa Yogyakarta menggambarkan keadaan Daerah Istimewa Yogyakarta yang merupakan daerah khusus atau istimewa dan negara menghormati daerah yang mempunyai sifat khusus atau istimewa. Pengisian jabatan gubernur dan Wakil Gubernur Daerah Istimewa Yogyakarta sudah sesuai dengan asas demokrasi, karena hakikat demokrasi itu sendiri adalah kehendak rakyat itu sendiri.

Kata kunci : Keistimewaan Yogyakarta, Pemerintah Daerah, Pengisian jabatan Gubernur dan Wakil Gubernur Daerah Istimewa Yogyakarta.

ABSTRACT

The Unitary State of the Republic of Indonesia recognizes and respects special or special regional government units compiled by law. The State also respects the unity of indigenous and tribal peoples and the rights of traditionality together alive and in accordance with the development of society and the principle of the Unitary State of the Republic of Indonesia, as governed by law. Given the above matters, the work undertaken by customary law bodies and the rights of common traditions is still evolving and developing with the community. With the provisions of the Special Privileges Act of Yogyakarta Special Region, Special Region of Yogyakarta which is a special area and special areas that have special or special properties. Filling the post of governor and Deputy
\end{abstract}


Governor of Yogyakarta Special Region has been in accordance with the principle of democracy, because the essence of democracy itself is the will of the people themselves.

Keywords: Privileges Yogyakarta, Local Government, Charging Office Governor and Deputy Governor of Yogyakarta Special Region

\section{A. PENDAHULUAN}

\section{Latar Belakang}

Negara Republik Indonesia sebagai Negara Kesatuan menganut asas desentralisasi dalam penyelenggaraan pemerintahan di daerah. Pelaksanaan desentralisasi yang menghasilkan otonomi tersebut dijalankan dan di kembangkan dalam dua nilai dasar, yaitu nilai unitaris dan nilai desentralisasi territorial. Nilai dasar unitaris diwujudkan dalam pandangan Negara Kesatuan Republik Indonesia tidak akan mempunyai kesatuan pemerintah lain di dalamnya yang bersifat Negara. Artinya, kedaulatan yang melekat pada rakyat, bangsa, dan Negara Republik Indonesia tidak akan terbagi di antara kesatuan pemerintahan. Sementara itu, nilai dasar desentralisasi territorial diwujudkan dalam penyelenggaraan pemerintahan di daerah dalam bentuk otonomi. ${ }^{1}$

Secara subtansial posisi dasar pemerintah yang berkaitan dengan Undang-Undang tentang Keistimewaan Daerah Istimewa Yogyakarta atau tentang pemerintahan Daerah Istimewa Yogyakarta terdapat 3 (tiga) esensi pokok, yaitu: Pertama, pilar keistimewaan DIY bertumpu pada sistem nasional yaitu Negara Kesatuan Republik Indonesia yang dalam UUD N RI Tahun 1945 sebagaimana telah diatur dengan jelas (Pasal 18). Kedua, pemahaman keistimewaan Daerah Istimewa Yogyakarta harus merujuk pada bentangan sejarah, dan aspek-aspek lain yang memang harus diperlakukan secara khusus, sebagaimana pula yang diatur dalam Undang-undang Dasar serta harus nampak dalam struktur pemerintahan keistimewaan. Ketiga, mengingat NKRI adalah negara hukum dan negara demokrasi. Nilai-nilai demokrasi (democratic values), tidak boleh diabaikan karena tentu tidak mungkin ada sistem monarkhi yang bertabrakan, baik dengan konstitusi maupun dengan nilai-nilai demokrasi.

\section{Rumusan Masalah}

Dalam uraian di atas maka penulis merumuskan masalah yang akan diteliti adalah sebagai berikut :

a. Bagaimana Sejarah Keistimewaan Daerah Istimewa Yogyakarta?

1 Hari Sabarno, Untaian Pemikiran Otonomi Daerah Memandu Otonomi Daerah Menjaga Kesatuan Bangsa, Sinar Grafika,Jakarta,2008,hal. 3 
b. Bagaimana Proses Pengisian Jabatan Gubernur dan Wakil Gubernur Daerah Istimewa Yogyakarta menurut Undang-Undang Nomor 13 Tahun 2012 di Yogyakarta?

c. Bagaimana Kehendak Masyarakat Daerah Istimewa Yogyakarta Dalam Pengisian Jabatan Gubernur dan Wakil Gubernur?

\section{Tujuan Penelitan}

Adapun tujuan dari penelitian ini adalah sebagai berikut :

a. Untuk mengetahui sejarah munculnya keistimewaan di Yogyakarta yang tetap bertahan hingga sekarang.

b. Untuk mengetahui Proses Pengisian Jabatan Gubernur dan Wakil Gubernur Daerah Istimewa Yogyakarta menurut Undang-Undang Nomor 13 Tahun 2012 di Yogyakarta.

c. Untuk mengetahui Kehendak Masyarakat Daerah Istimewa Yogyakarta Dalam Pengisian Jabatan Gubernur dan Wakil Gubernur.

\section{Manfaat Penelitian}

Kegunaan penelitian diharapkan dapat dipergunakan baik secara teoritis maupun praktis.

a. Secara teoritis dapat berguna dalam perkembangan ilmu pengetahuan dibidang hukum umumnya dan bidang hukum tata usaha negara khususnya.

b. Secara praktis diharapkan dapat berguna bagi Pemerintah Daerah dalam mengambil kebijaksanaan, bagi masyarakat pada umumnya, serta Penulis pada khususnya.

\section{Tinjauan Pustaka}

\section{a. Negara Kesatuan}

Yang dimaksud dengan Negara Kesatuan ialah suatu negara yang merdeka dan berdaulat, dimana diseluruh negara yang berkuasa hanyalah satu pemerintah yang mengatur seluruh daerah, jadi tidak terdiri atas beberapa daerah yang berstatus negara bagian (deelstaat). Negara Kesatuan merupakan negara tunggal, negara yang terdiri dari satu negara saja betapapun besar dan kecilnya, dan kedalam maupun keluar merupakan kesatuan. Negara Kesatuan merupakan negara tunggal, mewujudkan kesatuan, unity, dan yang monocentris (berpusat satu). Mengenai bentuk negara kesatuan, menurut C.F. Strong negara kesatuan ialah bentuk negara dimana wewenang legislatif tertinggi dipusatkan dalam suatu badan legislatif nasional/pusat.

Pengkajian tentang komitmen untuk tetap mempertahankan Negara Kesatuan dengan kondisi penyelenggaraan pemerintahan yang berada pada sistem pemerintahan yang cenderung menganut sistem pemerintahan yang federal menjadi masalah yang tidak hentinya menimbulkan persoalan yang berkaitan dengan hubungan pemerintahan antara pemerintah dengan Pemerintah Daerah, berdasarkan pengkajian yang dilakukan penulis dengan menggunakan pendekatan perundang-undangan (statute approach) dan pendekataan kepustakaan (conceptual approach) 
ditemukan bahwa Konsep Negara Kesatuan yang menjadi bentuk Negara Indonesia dengan penerapan kebijakan desentralisasi dalam penyelenggaraan Pemerintahan Daerah sebagai suatu kebijakan pembagian urusan tidak relevan.

\section{b. Pemerintahan Daerah}

Sistem penyelenggaraan pemerintahan di Indonesia meliputi sistem Pemerintahan Pusat atau disebut pemerintah dan sistem Pemerintahan Daerah. Praktik penyelenggaraan pemerintahan dalam hubungan antar pemerintah, dikenal dengan konsep sentralisasi dan desentralisasi. Konsep sentralisasi menunjukkan karakteristik bahwa semua kewenangan penyelenggaraan pemerintahan berada di Pemerintah Pusat, sedangkan sistem desentralisasi menunjukkan karakteristik yakni sebagian kewenangan urusan pemerintahan yang menjadi kewajiban pemerintah, diberikan kepada Pemerintah Daerah. Sistem desentralisasi pemerintahan tidak pernah surut dalam teori maupun praktik Pemerintahan Daerah dari waktu ke waktu.

Untuk Pemilihan Kepala Daerah (Pilkada), baik Provinsi maupun Kabupaten/Kota, melalui ketentuan Pasal 18 ayat (4) UUD N RI Tahun 1945 dinyatakan bahwa "Gubernur, Bupati, dan Walikota masing-masing sebagai kepala Pemerintahan Daerah Provinsi, Kabupaten, dan Kota dipilih secara demokratis". Rumusan ini telah menimbulkan permasalahan pertama, yaitu bahwa Pilkada dapat dilakukan secara langsung seperti halnya pemilihan Presiden dan Wakil Presiden, atau secara tidak langsung yaitu oleh Dewan Perwakilan Rakyat Daerah (DPRD) seperti yang dipraktekkan sebelumnya dan yang diatur dalam Undang-Undang Nomor 22 Tahun 1999 tentang Pemerintahan Daerah. Sedangkan menurut Undang-Undang Nomor 32 Tahun 2004 tentang Pemerintahan Daerah yang menggantikan Undang-Undang Nomor 22 Tahun 1999 menafsirkan bahwa Kepala Daerah dipilih secara demokratis, hal tersebut mengandung maksud Kepala Daerah dipilih langsung oleh rakyat. ${ }^{2}$

\section{c. Tata Cara Pengisian Kepala Daerah Menurut Undang-undang Nomor 22 Tahun 1999 dan Undang-undang Nomor 32 Tahun 2004}

Pelaksanaan tata cara pengisian Kepala Daerah menurut Undang-undang Nomor 22 Tahun 1999 sangat berbeda sekali dengan Undang-undang Nomor 32 tahun 2004. Menurut pasal Undangundang Nomor 22 tahun 1999 semua tata cara pengisian Kepala Daerah dari penetapan calon Kepala Daerah, pemilihan Kepala Daerah, penyampaian visi misi calon Kepala Daerah, panitia pemilihan semuanya dan lain-lain dilakukan oleh DPRD. Hal ini berbeda sekali dengan Undangundang Nomor 32 Tahun 2004 dimana tata cara pengisian Kepala Daerah dipilih oleh rakyat

2 Abdul Mukthie Fadjar, Hukum Konstitusi dan Mahkamah Konstitusi, Sekretariat Jenderal dan Kepaniteraan Mahkamah Konstitusi RI, Jakarta, 2006, hal. 102 
melalui pemilihan langsung Kepala Daerah. Sedangkan perangkat pelaksanaan pemilihan Kepala Daerah dilakukan oleh Komisi Pemilihan Umum Daerah (KPUD).

Sering kita mendengar isu politik uang dalam proses pemilihan Kepala Daerah dan Wakil Kepala Daerah oleh DPRD. Masalah politik uang ini terjadi karena begitu besarnya wewenang yang dimiliki oleh DPRD dalam proses pemilihan Kepala Daerah dan Wakil Kepala Daerah. Oleh karena itu, apabila dilakukan pemilihan Kepala Daerah secara langsung kemungkinan terjadinya politik uang bisa dicegah atau setidaknya dikurangi.

Sesuai dengan Undang-Undang Nomor 22 Tahun 1999, pertanggungjawaban Kepala Daerah kepada DPRD merupakan kewajiban Pemerintah Daerah untuk menjelaskan kinerja penyelenggaraan pemerintahan kepada masyarakat tetapi untuk Gubernur sebagai wakil Pemerintah Pusat di daerah harus melaporkan pertanggungjawabannya ke pusat juga. Dalam Undang-Undang Nomor 22 Tahun 1999 seorang Kepala Daerah dapat memperbaiki laporan tersebut selama 30 hari, Sedangkan dalam Undang-undang Nomor 32 tahun 2004 tidak mengatur mengenai waktu memperbaiki penolakan laporan pertanggungjawaban dari Kepala Daerah. Dan pada Undang-undang nomor 22 tahun 1999 seorang Kepala Dearah dapat diusulkan untuk diberhentikan oleh DPRD kepada Presiden, karena Laporan Pertanggungjawaban (LPJ) Kepala Daerah yang bersangkutan ditolak untuk kedua kalinya oleh DPRD.

\section{d. Pemilihan Pemimpin Menurut Perspektif Islam}

Islam adalah sebuah totalitas yang padu yang menawarkan pemecahan terhadap semua masalah kehidupan. Sebagai agama rahmatan lil'alamin Islam sarat dengan aturan-aturan hukum yang menjadi acuan manusia dalam menjalani hidup dan kehidupannya di setiap bidang yang digelutinya, termasuk kehidupan keluarga, ekonomi, dan politik. Aturan-aturan Islam itu secara umum bisa dikelompokkan menjadi dua, satu aturan hukum terkait dengan hubungan manusia dengan Tuhannya (hablun minallah) dan satu aturan hukum lagi terkait dengan hubungan manusia dengan sesama makhluk Tuhan (hablun minannas). Macam hubungan yang pertama itu kemudian disebut ibadah dan macam hubungan yang kedua disebut muamalah.

Dari beberapa ayat Al-Quran, dapat dijelaskan bahwa seorang Muslim harus memilih pemimpin yang Muslim. Allah berfirman dalam QS. An-nisa :144:

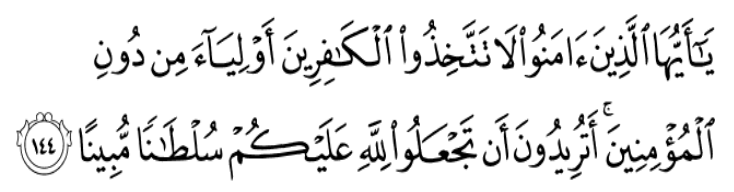

Hai orang-orang yang beriman, janganlah kamu mengambil orang-orang kafir menjadi wali dengan meninggalkan orang-orang mukmin. Inginkah kamu mengadakan alasan yang nyata bagi Allah (untuk menyiksamu)? (QS. an-Nisa' (4): 144). 
Wali dalam ayat ini bisa berarti pelindung, penolong, atau pemimpin. Dalam ayat yang lain Allah dengan tegas melarang umat Islam memilih pemimpin yang beragama Nasrani (Kristen/Katolik) atau beragama Yahudi (QS. al-Maidah (5): 51).

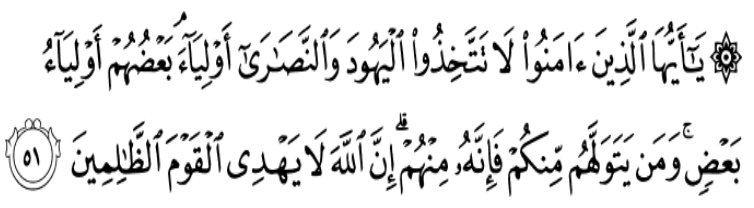

Hai orang-orang yang beriman, janganlah kamu mengambil orang-orang Yahudi dan Nasrani menjadi pemimpin-pemimpin(mu); sebagian mereka adalah pemimpin bagi sebagian yang lain. Barangsiapa diantara kamu mengambil mereka menjadi pemimpin, maka sesungguhnya orang itu termasuk golongan mereka. Sesungguhnya Allah tidak memberi petunjuk kepada orang-orang yang zalim (QS. al-Maidah (5): 51).

Allah juga menegaskan dalam QS. Al-maidah 57:

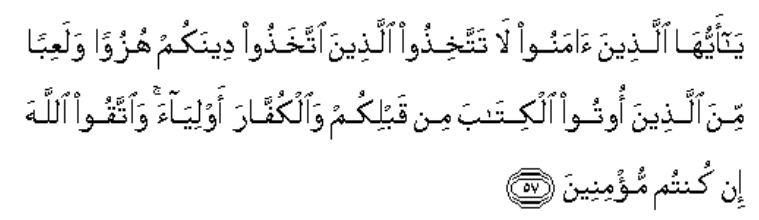

Hai orang-orang yang beriman, janganlah kamu mengambil jadi pemimpinmu, orang-orang yang membuat agamamu jadi buah ejekan dan permainan, (yaitu) di antara orang-orang yang telah diberi kitab sebelummu, dan orang-orang yang kafir (orang-orang musyrik). Dan bertakwalah kepada Allah jika kamu betul-betul orang-orang yang beriman (QS. al-Maidah (5): 57).

Tiga ayat ini memang terkesan mengajak umat Islam harus "fanatik". Mengapa al-Quran menegaskan hal ini, apakah ada toleransi untuk memilih pemimpin yang non-Muslim? ketiga ayat itu harus dipahami secara kontekstual. Ketika kita dihadapkan pada pilihan yang beragam agamanya, ada yang Muslim dan ada yang non-Muslim, maka di sinilah kita dituntut ketegasan untuk memilih yang Muslim. Lalu apa yang harus kita lakukan ketika calon pemimpin yang kita pilih itu semua Muslim atau semuanya non-Muslim, atau mungkin juga dihadapkan pada pilihan yang dilematis, misalnya dua calon pemimpin yang harus kita pilih salah satunya Muslim tetapi tidak berkualitas (jelek) dan satunya lagi berkualitas (baik) tetapi non-Muslim.

Karena itu, jika kita dihadapkan pada dua calon pemimpin, yang satu Muslim tetapi jelek dan yang satu non-Muslim tetapi baik, maka kita harus lebih cermat lagi dalam melakukan pilihan. Lebih baik memilih calon pemimpin yang Muslim meskipun jelek lebih baik daripada memilih calon pemimpin yang baik tetapi non-Muslim. Dalam pandangan Islam kedua calon pemimpin itu sama-sama tidak baik (kurang), sehingga yang harus dipilih adalah yang paling minim 
kekurangannya. Argumen yang bisa dipegangi adalah membuat orang yang jelek menjadi baik lebih mudah ketimbang membuat orang yang non-Muslim menjadi Muslim.

\section{B. METODE PENELITIAN}

1. Pendekatan Penelitian

Pendekatan penelitian menggunakan metode pendekatan Sosio Legal Research, yaitu dengan menggabungkan antara metode pendekatan yang bersifat normatif dan metode pendekatan yang bersifat empiris. ${ }^{3}$ Dengan demikian penelitian hukum tidak terkungkung menjadi penelitian dogmatis sekaligus juga tidak ke luar menjadi penelitian non hukum.

2. Spesifikasi Penelitian

Spesifikasi penelitian ini menggunakan metode deskriptif analisis, yaitu dengan menggambarkan dan memberikan data yang diteliti dan secermat mungkin tentang suatu permasalahan yang maksudnya untuk memperkuat teori-teori yang sekaligus dapat menyusun kerangka teori baru. ${ }^{4}$

3. Subyek Penelitian

Penulis memilih Pamong desa, tokoh masyarakat di Kabupaten Bantul Yogyakarta serta abdi Dalem di Kasultanan Yogyakarta sebagai subyek penelitian.

4. Lokasi Penelitian

Lokasi penelitian ini adalah di Kabupaten Bantul Yogyakarta dan Kasultanan Yogyakarta.

5. Jenis dan Sumber Data

a. Jenis Data

Jenis data yang digunakan dalam penelitian ini adalah data sekunder, yakni data yang diperoleh melalui bahan kepustakaan. Data sekunder yang dibutuhkan dalam penelitian hukum ini antara lain dapat diperoleh dari beberapa literatur, Jurnal, majalah dan bahan hukum sekunder lainnya yang terkait dengan penelitian ini.

b. Sumber Data

1) Data Primer digunakan sebagai data utama yaitu data yang diperoleh dari hasil tanya jawab atau wawancara dengan Pamong Desa, warga, tokoh masyarakat Kabupaten Bantul Yogyakarta, dan Kasultanan Yogyakarta .

3 Bambang Waluyo, Penelitian Hukum Dalam Praktek, Sinar Grafika, Jakarta, 1991, hal. 17

${ }^{4}$ Soerjono Sukanto, Pengantar Penelitian Hukum, UI Press, Jakarta, 1985, hal. 8 
2) Data sekunder, antara lain mencakup dokumen-dokumen resmi, buku-buku, hasil-hasil penelitian yang berwujud laporan, buku harian, dan seterusnya.

6. Tehnik Pengumpulan Data

a. Studi kepustakaan, yaitu dengan mempelajari buku-buku yang ada kaitannya dengan judul.

b. Observasi, yaitu melakukan pengumpulan data dengan mengadakan pengamatan secara langsung terhadap obyek dan melakukan pencatatan secara sistematik tentang hal yang diamati.

c. Wawancara, yaitu dengan wawancara yang bersifat bebas terpimpin dalam penyajiannya disesuaikan dengan situasi dan kondisi subyek. Menggunakan jenis Sample purposive, sampel dipilih berdasarkan penilaian peneliti bahwa dia adalah pihak yang paling baik untuk dijadikan sampel penelitiannya. Sample purposive adalah salah satu cara yang diambil peneliti untuk memastikan, bahwa unsur tertentu dimasukkan ke dalam sample. ${ }^{5}$

7. Metode Analisa Data

Data yang diperoleh atau dikumpulkan disusun secara deskriptif kualitatif. Metode analisis deskriptif kualitatif yaitu menganalisis, menggambarkan dan meringkas berbagai kondisi, situasi dari berbagai data yang dikumpulkan berupa hasil dari wawancara atau pengamatan mengenai masalah yang diteliti yang terjadi di lapangan.

\section{HASIL PENELITIAN DAN PEMBAHASAN}

\section{Sejarah Keistimewaan Yogyakarta}

\section{a. Sejarah Terbentuknya Yogyakarta}

Terbentuknya Yogyakarta bermula dari perselisihan internal yang terdapat di Kerajaan Mataram antara Raja Mataram Paku Buwono II (1719-1749) dan Kanjeng Pangeran Aryo Mangkubumi. Perselihan berkepanjangan dimulai karena adanya pembatalan secara sepihak dari Paku Buwono II terhadap pemberian tanah di Sukowati. Pertikaian pun terus berlanjut hingga Paku Buwono III. Di sinilah kemudian Belanda memanfaatkan konflik internal Kerajaan Mataram dengan menjadi penengah sekaligus menawarkan solusi yang bisa diterima oleh kedua belah pihak. Melalui solusi ini, Belanda bermaksud untuk mengkerdilkan kekuatan Mataram dengan membagi

5 James A. Black dan Dean J. Champion, Metode \& Masalah Penelitian Sosial, Refika Aditama, Bandung, 2009, hal.264 
atau mempersempit wilayah kekuasaan Raja Mataram. Di sini lah Belanda kemudian menawarkan solusi dengan membuat Perjanjian Gianti pada tanggal 13 Pebruari 1755.

Perlawanan yang dilakukan oleh Pangeran Aryo Mangkubumi bukan ditujukan kepada Paku Buwono II/III, akan tetapi ditujukan kepada pihak kumpeni (Belanda). Perlawanan oleh Pangeran Aryo Mangkubumi dikarenakan pihak Belanda bermaksud menjalankan taktik untuk memecah-mecah kekuasaan Mataram dan sekaligus mengatur kekuasaan Paku Buwono II dengan menjauhkannya dari lingkungan keluarga kerajaan. Salah satunya dengan memindahkan ibukota Mataram yang semula terletak di Kartasura ke Surakarta yang dilakukan tanpa pertimbangan atau pendapat dari Pangeran Mangkubumi. Dengan memberikan wilayah yang relatif sama dengan kekuasaan Kerajaan Surakarta ketika itu, tentunya menjadi pertimbangan bagi Pangeran Mangkubumi untuk menyusun kekuatan melawan Belanda. ${ }^{6}$

Pada tahun 1813 didirikan pemerintahan baru yang disebut Kadipaten Pakualaman yang dipimpin oleh Bendoro Pangeran Notokusumo yang merupakan putera dari Sultan HB I. Semasa pemerintahan Sultan HB III, Pangeran Notokusumo kemudian diangkat menjadi Pangeran Merdeka dengan gelar Kanjeng Gusti Pangeran Adipati Pakualaman I. Dengan berdirinya Kadipaten Pakualaman, wilayah kekuasaan Ngayogyakarta Hadiningrat mengalami sedikit perubahan. Peta wilayah kekuasaan Mataram merupakan hasil akhir dari keseluruhan upaya Belanda untuk memecah kekuatan perlawanan Mataram.

\section{b. Sejarah Setelah Kemerdekaan 1945}

Sekalipun berdiri sebagai salah satu wilayah kerajaan di Pulau Jawa, Ngayogyakarta Hadiningrat tidak menutup pintu untuk setiap upaya yang dilakukan oleh tokoh-tokoh pergerakan nasional. Tidak sedikit peristiwa-peristiwa pergerakan nasional yang tumbuh dan dimulai di Kerajaan Ngayogyakarta Hadiningrat. Misalnya Kongres Perempuan I (1928), Taman Siswa (1922), Kongres I Budi Utomo (1908), berdirinya organisasi Muhammadiyah. Kontribusi kerajaan ini cukup besar terhadap perjuangan nasional dalam rangka upaya untuk mencapai kemerdekaan Indonesia.

Paska Proklamasi 17 Agustus 1945, beberapa minggu sesudahnya Sri Sultan Hamengku Buwono IX mendapatkan desakan untuk segera membuat resolusi kerajaan. Dengan mempertimbangkan kondisi Republik Indonesia yang ketika itu sangat membutuhkan dukungan nasional, Sri Sultan Hamengku Buwono IX mengeluarkan dekrit kerajaan yang disebut Amanat 5 September 1945. Pada prinsipnya, isi dekrit kerajaan adalah melakukan integrasi monarki

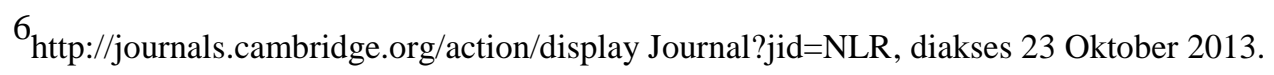


Ngayogyakarta Hadiningrat ke dalam NKRI. Dekrit Amanat 5 September 1945 ini kemudian diikuti pula oleh dekrit yang dikeluarkan oleh Paku Alam VIII pada tanggal yang bersamaan. Dekrit integrasi ke dalam NKRI sesungguhnya juga dikeluarkan pula oleh berbagai kerajaan/monarki di seluruh wilayah Nusantara. Secara politik, Amanat 5 September 1945 memberikan dampak yang luar biasa dan mempengaruhi kerajaan-kerajaan nusantara lain untuk segera bergabung dengan NKRI.

2. Proses Pengisian Jabatan Gubernur dan Wakil Gubernur Daerah Istimewa Yogyakarta menurut Undang-Undang Nomor 13 Tahun 2012

Proses pemilihan gubernur dan wakil gubernur akan melalui beberapa tahap. Mulai dari pencalonan, Verifikasi , Penetapan, Pelantikan Gubernur dan Wakil Gubernur.

a. Tahap Pengajuan Calon

1) DPRD DIY memberitahukan kepada Gubernur dan Wakil Gubernur serta Kasultanan dan Kadipaten tentang berakhirnya masa jabatan Gubernur dan Wakil Gubernur paling lambat 3 (tiga) bulan sebelum berakhirnya masa jabatan Gubernur dan Wakil Gubernur.

2) Berdasarkan pemberitahuan dari DPRD DIY sebagaimana dimaksud pada ayat (1), Kasultanan mengajukan Sultan Hamengku Buwono yang bertakhta sebagai calon Gubernur dan Kadipaten mengajukan Adipati Paku Alam yang bertakhta sebagai calon Wakil Gubernur paling lambat 30 (tiga puluh) hari setelah surat pemberitahuan DPRD DIY diterima.

3) Kasultanan dan Kadipaten pada saat mengajukan calon Gubernur dan calon Wakil Gubernur kepada DPRD DIY menyerahkan:

a). surat pencalonan untuk calon Gubernur yang ditandatangani oleh Penghageng Kawedanan Hageng Panitrapura Kasultanan Ngayogyakarta Hadiningrat;

b). surat pencalonan untuk calon Wakil Gubernur yang ditandatangani oleh Penghageng Kawedanan Hageng Kasentanan Kadipaten Pakualaman;

c). surat pernyataan kesediaan Sultan Hamengku Buwono yang bertakhta sebagai calon Gubernur dan Adipati Paku Alam yang bertakhta sebagai calon Wakil Gubernur;

d). kelengkapan persyaratan lainnya

\section{b. Tahap Verifikasi dan Penetapan}

DPRD DIY melakukan verifikasi terhadap dokumen persyaratan Sultan Hamengku Buwono sebagai calon Gubernur dan Adipati Paku Alam sebagai calon Wakil Gubernur. Dalam melakukan verifikasi sebagaimana dimaksud DPRD DIY membentuk Panitia Khusus Penetapan Gubernur dan Wakil Gubernur. Panitia Khusus Penetapan Gubernur dan Wakil Gubernur dibentuk 
dengan keputusan pimpinan DPRD DIY. Panitia Khusus Penetapan Gubernur dan Wakil Gubernur bertugas sebagai penyelenggara dan penanggung jawab penetapan Gubernur dan Wakil Gubernur.

c. Tahap Pelantikan Gubernur dan Wakil Gubernur

Pelantikan Gubernur dan/atau Wakil Gubernur dilakukan oleh Presiden. Dalam hal Presiden berhalangan, pelantikan Gubernur dan/atau Wakil Gubernur dilakukan oleh Wakil Presiden. Dalam hal Presiden dan Wakil Presiden berhalangan, pelantikan Gubernur dan/atau Wakil Gubernur dilakukan oleh Menteri.

\section{Kehendak Masyarakat Daerah Istimewa Yogyakarta Dalam Pengisian Jabatan Gubernur dan Wakil Gubernur}

Pada saat proses pembentukan Undang-undang Keistimewaan Yogyakarta warga jogja bahkan menyuarakan aspirasinya melalui rencana pemboikotan pemilihan Gubernur jika bukan menetapkan langsung Sultan sebagai Gubernur melainkan melalui pemilihan umum. Dilihat lebih jauh di sini tersirat ada kehendak rakyat untuk mewakilkan atau menyerahkan kedaulatan pada pemimpin yang mereka percayai yakni Sri Sultan Hamengku Buwono X sebagai gubernur dan Paku Alam sebagai wakilnya.

Hal yang tidak menjadi tujuan semula bisa terjadi jika pemerintah bersikeras untuk melangkahi kedaulatan rakyat sebagai kedaulatan tertinggi, dan boleh jadi rakyat mengganti pemerintahan bilamana tidak sesuai dengan kehendak rakyat. Sedikit perlu diingat dalam hal ini bukan hanya tentang kehendak rakyat pada siapa pemimpin pemerintahan, namun juga menyangkut status keistimewaan suatu daerah asal-muasalnya adalah diberikan dari pemerintah itu sendiri.

\section{SIMPULAN}

Dari hasil penelitian yang diuraikan dalam bentuk tesis di atas maka simpulan yang didapat adalah:

1. Daerah Istimewa Yogyakarta memiliki sejarah yang khas, Kekhasan itu menyangkut bukan saja kontribusi DIY dalam mendirikan dan menjaga eksistensi NKRI, tapi juga secara simbolik dan aktual dalam mengisi visi keIndonesiaan secara lebih kongkret.

2. Proses pemilihan gubernur dan wakil gubernur akan melalui beberapa tahap, antara lain:
a. Tahap Pengajuan Calon
b. Tahap Verifikasi dan Penetapan
c. Tahap Pelantikan Gubernur dan Wakil Gubernur

3. Bagi rakyat Yogyakarta, Sultan Hamengku Buwono X bukan sekadar pemimpin politik dan pemerintahan. Di atas segalanya, Sultan Hamengku Buwono X tokoh moral dan pemimpin budaya. 


\section{E. DAFTAR PUSTAKA}

\section{BUKU}

Abdul Mukthie Fadjar, Hukum Konstitusi dan Mahkamah Konstitusi, Sekretariat Jenderal dan Kepaniteraan Mahkamah Konstitusi RI, Jakarta, 2006.

Ali Mansyur, Pranata Hukum dan Penegakannya di Indonesia, Unissula Press, Semarang, 2010. Andi Mustain Pide, Otonomi Daerah dan Kepala Daerah Memasuki Abad XXI, Gaya Media Pratama, Jakarta, 1998.

Ateng Safrudin, Pasang Surut Otonomi Daerah, Bina Cipta, Bandung, 1985.

A. Hamid S. Attamimi, Peranan Keputusan Presiden Republik Indonesia Dalam Penyelenggaraan Pemerintahan Negara, Disertasi, UI-Jakarta, 1990.

Baban Sobandi Dkk., Desentralisasi dan Tuntutan Kelembagaan Daerah, Humaniora, Bandung, 2005.

Bagir Manan, Hubungan Natara Pemerintah Pusat dan Daerah Menurut UUD 1945, $\quad$ Pustaka Sinar Harapan, Jakarta, 1994.

Bambang Waluyo, Penelitian Hukum Dalam Praktek, Sinar Grafika, Jakarta, 1991.

Bambang Yudoyono, Otonomi Daerah, Pustaka Harapan, Jakarta, 2002.

BN Marbun, DPRD Pertumbuhan dan Cara Kerjanya, Pustaka Sinar Harapan, Jakarta, 2005.

Didik Sukriono, Pembaharuan Hukum Pemerintah Desa Politik Hukum Pemerintahan Desa di Indonesia, Setara Press, Malang, 2010.

HAW Widjaja, Penyelenggaraan Otonomi di Indonesia, PT Raja Grafindo Persada , Jakarta, 2005.

Hari Sabarno, Untaian Pemikiran Otonomi Daerah Memandu Otonomi Daerah Menjaga Kesatuan Bangsa, Sinar Grafika,Jakarta,2008.

I Gde Pantja Astawa, Problematika Hukum Otonomi Daerah Di Indonesia, $\quad$ Alumni, Bandung, 2008.

James A. Black dan Dean J. Champion, Metode \& Masalah Penelitian Sosial, $\quad$ Refika Aditama, Bandung, 2009.

Jimly Asshiddiqie, Konstitusi \& Konstitusionalisme Indonesia, Sekretariat Jenderal Mahkamah Konstitusi RI, Jakarta, 2006.

J.R. Kaho, Prospek Otonomi Daerah di Negara Republik Indonesia Identifikasi Beberapa Faktor Yang Mempengaruhi Penyelenggaraannya, PT Raja ～Grafindo Persada, Jakarta, 1997. Koirudin, Sketsa Kebijakan Desentralisasi di Indonesia Format Masa Depan Otonomi Menuju Kemandirian Daerah, Averroes Press, malang, 2005.

Mardiasmo, Otonomi dan Manajemen Keuangan Daerah, andi Offset, Yogyakarta, 2002. 
Miriam Budiardjo, Dasar-dasar Ilmu Politik, Gramedia Pustaka Utama, Jakarta, 1998.

Murtir Jeddawi, Implementasi Kebijakan Otonomi Daerah Analisis Kewenangan, Kelembagaan, Manajemen Kepegawaian, dan Peraturan Daerah, Kreasi Total Media, Yogyakarta, 2008.

M. Laica Marzuki, Berjalan-Jalan Di Ranah Hukum Pikiran-Pikiran Lepas, Sekretariat Jenderal dan Kepaniteraan Mahkamah Konstitusi RI, Jakarta, 2006.

M.R. Khairul Muluk, Desentralisasi dan Pemerintahan Daerah, Bayu Media, Malang, 2006.

Ni'matul Huda, Otonomi Daerah Filosofi Sejarah Perkembangan dan Problematika, Pustaka Pelajar,Yogyakarta, 2005.

-Hukum Pemerintahan Daerah, Nusamedia, Bandung, 2009.

Oentarto, Dkk., Menggagas Format Otonomi Daerah Masa Depan, Samitra Media Utama, Jakarta, 2004.

Santoso, Hubungan Ideal Pemerintah Pusat dan Daerah, Langgeng Press, $\quad$ Bandung, 2001.

Soerjono Sukanto, Pengantar Penelitian Hukum, UI Press, Jakarta, 1985.

Rahardjo Adisasmita, Manajemen Pemerintah Daerah, Graha Ilmu, Yogyakarta, 2011.

Rosjidi Ranggawidjaja, Pengantar Ilmu Perundang-undangan Indonesia, Mandar Maju, Bandung, 1998.

\section{PERATURAN PERUNDANG-UNDANGAN}

Undang-Undang Dasar Negara Republik Indonesia Tahun 1945

Undang-Undang Nomor 22 Tahun 1948 tentang Pemerintah Daerah

Undang-Undang Nomor 1 Tahun 1957 tentang Pokok-pokok Pemerintahan Daerah

Undang-Undang Nomor 18 Tahun 1965 tentang Pokok-pokok Pemerintahan Daerah

Undang-Undang Nomor 5 Tahun 1974 tentang Pokok-Pokok Pemerintahan di Daerah

Undang-Undang Nomor 22 Tahun 1999 tentang Pemerintahan Daerah

Undang-Undang Nomor 32 Tahun 2004 Tentang Pemerintahan Daerah

Undang-Undang Nomor 10 Tahun 2004 Tentang Pembentukan Peraturan Perundang-undangan

Undang-Undang Nomor 12 Tahun 2011 Tentang Pembentukan Peraturan Perundang-undangan

Undang-Undang Nomor 13 Tahun 2012 Tentang Keistimewaan Daerah Istimewa Yogyakarta

\section{LAIN-LAIN}

Ismu Gunadi Widodo, Sistem Penetapan Gubernur Kepala Daerah Istimewa Yogyakarta Dalam Sistem Pemilihan Kepala Daerah Berdasarkan Pasal 18 Ayat (4) UUD 1945, Jurnal Dinamika Hukum Universitas Bhayangkara Surabaya, Vol. 11, No.2, 2011. 
Tim Jurusan Ilmu Pemerintahan Fisipol UGM, Draft Naskah Akademik Rancangan UndangUndang Keistimewaan Provinsi Daerah Istimewa $\quad$ Yogyakarta, Yogyakarta, 2007. http://www.law.gmu.edu/gmucrlj/symposium.php, diakses tanggal 27 Oktober 2013. http://journals.cambridge.org/action/display Journal?jid=NLR, diakses 23 Oktober 2013. www.ygya2 plasa-diy.net, diakses tanggal 27 Oktober 2013.

http://Indonesia-like.blogspot.com/keistimewaan-yogyakarta-sejarah.html.Diakses Pebruari 2013

http://id.wikipedia.org/wiki/Otda, diakses tanggal 25 Pebruari 2014 